九州大学学術情報リポジトリ

Kyushu University Institutional Repository

\title{
Impacts of Reform Policies on Agricultural Sector in Vietnam
}

Hung, Pham Van

Faculty of Economics and Rural Development, Hanoi Agricultural University

Murata, Takeshi

Laboratory of Agricultural Policy, Division of International Agricultural Resource Economics and Business Administration, Department of Agricultural and Resource Economics, Faculty of Agriculture, Kyushu University

https://doi.org/10.5109/24431

出版情報: 九州大学大学院農学研究院紀要. 46 (1), pp. 165-183，2001-10-30. 九州大学農学部 バージョン：

権利関係 : 


\title{
Impacts of Reform Policies on Agricultural Sector in Vietnam
}

\author{
Pham Van HUNG* and Takeshi MURATA
}

\author{
Laboratory of Agricultural Policy, Division of International Agricultural Resource Economics \\ and Business Administration, Department of Agricultural and Resource Economics, \\ Faculty of Agriculture, Kyushu University, Fukuoka, 812-8581, Japan. \\ (Received May 31, 2001 and accepted July 11, 2001)
}

\begin{abstract}
In the last two decades, Vietnam has undergone dramatic changes due to policy reform. One of the great achievements which is not deniable is in the agricultural and rural sector. Agricultural reform first started in 1981 with a shift in responsibility for cultivation to farming households. Although the shift was only partial, this reform helped to unleash farmers, and output and efficiency responded significantly. The 1988-89 reforms swept away ambiguities: production means and other goods were returned to private ownership, production and distribution were liberalized and price controls abolished. In addition, liberalization of external trade and devaluation of the currency opened the economy to the world market. The 1993-94 reforms continued to speed up agricultural growth. The effects of reform policies are continuing to be felt up today and will be in the future. The analysis has shown that along with the yields, total output of agriculture has increased dramatically. This has led to a more efficient use of land, the scarcest production factor in Vietnam: Land. Agricultural and rural incomes have also improved and rural poverty has fallen. However, poverty is still a phenomenon of rural areas and ethnic minority groups. In recent ycars, agricultural productivity growth has slowed; income disparities between regions and groups of people have expanded; unemployment and underemployment in rural areas are more severe, etc. For further development particularly in meeting the targets of the Ten-Year Socio-Economic Development Plan (2001-2010) drafted by the Government in 2000 , Vietnam needs to have simultaneous policies to develop not only agriculture but also other sectors.
\end{abstract}

\section{INTRODUCTION}

The Vietnamese economy has undergone vast changes since the implementation of the "Doi Moi" reforms (renovation policy) in 1986. However, reforms in the agricultural sector had been carried out a decade earlier particularly with the implementation of the Decree No. 100 of the Central Committee of the Communist Party (1981), that gave increasingly greater autonomy to individual households. Since then, Vietnamese agriculture and rural areas have experienced dramatic changes. In the last decade (1989-99), the gross output of agriculture has been growing at an average of 5.39 percent annually and farmers have more than doubled rice output. Outputs of non-rice food crops (soybean, vegetables, etc.), commercial and industrial crops (coffee, tca, rubber, cotton, etc.), livestock and aquaculture also expanded significantly. Despite the effects of the Asian financial crisis and the floods that damaged the Central regions in the last months of 1999 , the gross output of agriculture increased by 7.1 percent and agricultural GDP

* Lecturer, Faculty of Economics and Rural Development, Hanoi Agricultural University, Vietnam A JICA participant of HAU-JICA ERCB project A team member of ACIAR project 1/1997/092 
growth above 5.percent in the same year. The success of the rice sector contributed to the achievement of food security at the aggregate level and to significant foreign exchange earnings from exports ${ }^{1}$. In 1999, rice output rose to 31 million tons from 29 million tons in $1998^{2}$ (GSO, 2000). Since 1996, Vietnam has transformed into the world's second largest rice exporter behind Thailand. In 1999, the rice exports were a record 4.5 million tons and the value reached over the US $\$$ one billion threshold and accounted for 9 percent of total export revenue ${ }^{3}$. The livestock sector also increased in stability by 5.56 percent annually during the period of 1989-99. The main reason for these achievements is policy reforms. During the last two decades, many policies for agricultural and rural development were promulgated by the Government. Some policy had effect both directly and others indirectly. Three big policies that have had big impacts on the agricultural sector and rural areas in Vietnam are (1) Decree 100 (1981) on "output contract" system; (2) Resolution 10 (1988) on "complete output contract" system encouraging and considering the farm household as an autonomous economic unit; and (3) Law on Land (1993) and Ordinance 64/CP (1993) on the allocation of agricultural land to farm households and individuals for stable and long term use. The main purposes of these policies are agricultural and rural development including changes in agricultural land use. This means that the process of reforms in the agricultural sector can be classified into three stages (1) from 1981 to 1988; (2) from 1989 to 1993; and (3) from 1994 onwards.

In this paper, the authors would like to draw attention to the changes in agriculture in Vietnam during the three above mentioned periods particularly a last decade (after 1988). The achievements of the cultivation's sector is particularly of concern. An analysis is made mainly by using statistical or secondary data and by using the experiences of the authors from surveys in the North in 1990, 1992, 1997, and 1999. The paper is organized as follows: the following section summarises main points of the three above mentioned policies. Achievements of agriculture in the last two decades will be pointed out in the third section which is divided into three periods. The fourth section analyzes the constraints and challenges currently facing agriculture nowadays. Followed by a conclusion and policy implications are in concern in the last section.

\section{OVERVIEW OF THE MAIN POLICIES}

\section{Decree No. 100 CT/TW (13 January 1981) of the Central Committee of the Communist Party on the improvement of "contract activities", expansion of "output contract" to farming groups and individuals in agricultural cooper- atives}

\footnotetext{
${ }^{1}$ In the last years, the earnings from rice export surpassed US $\$$ one billion threshold (US $\$ 1.024$ and 1.025 billion with an average prices of US $\$ 273.15$ and 227.38 per ton for the year 1998 and 1999 , respectively).

${ }^{2}$ In the same year (1999), the paddy equivalent including rice and other cereals (maize, cassava, etc.) rose to 34 million tons from 31.85 million tons in 1998.

${ }^{3}$ In 1999, Vietnam's total export grew at 23.4 percent, reaching a total value of US $\$ 11.52$ billion at the end of the year from US\$ 9.338 billion in 1998 (WB Vietnam, 2000).

"Also referred to as "Contract 100 " called by some researchers and farmers.
} 
This was the first big reform in agriculture that allowed agricultural cooperatives entered into an "output contract" with farming groups and individuals. This system was also called "three contracts" system ${ }^{4}$ because agricultural cooperatives assigned utilization of agricultural land to farming groups and individuals and contracted the carrying out of three stages of farming such as transplanting; caring (including spraying fertilizers, pesticides, water supply, weeding control, etc.); and harvesting. The other remaining stages were still under the control of agricultural cooperatives' control. Farmers can get income in kind and based on the output levels produced and labor input throughout three stages. Initially there was a positive supply response to these early reform, only to see growth to peter out due to bottlenecks posed by the basic structures of the economy (Vali Jamal and Karel Jansen, 1998). Although the contract system under Decree 100 was still simple, but it made great contribution to agricultural growth in that period. However, this system gave limited freedom to agricultural cooperatives and was not sustainable and had weaknesses in the later years (1986-88). (For instance, the growth rates of gross output of food (paddy equivalent) were declined from 12.15 percent in 1982 to 2.64 percent annually in the period of 1983-85; only 0.98 percent in 1986 and in 1987, it decreased by 4.44 percent $)^{5}$.

\section{Resolution No. 10 NQ/TW (5 April 1988) of the Politburo of the Central Committee of the Communist Party on renovation of agricultural economic management}

This policy was enacted due to decline of agricultural production and the socio-economic situations happening in the period of 1985-87. The main ideas of this policy were recognise the farm household as an autonomous economic unit; the market-oriented economy (markets of inputs and outputs, and means of production (except land)); liberalization of prices; and demise of collectives. Farmers could sell or buy freely in the markets all their outputs and inputs of production. Under this policy, farmers were allocated land for stable use for 15 years and assigned "contract levels" (inputs used, outputs, labors, etc.) stable for 5 years. In fact, agricultural land especially in the North was divided into two funds (except for 5 percent of land) called first and second fund (in some cases third fund) ${ }^{6}$. The differences between the first and second fund were that the first fund was distributed equally per capita "equivalent", ", the second fund was allocated to households which had enough labors, experiences, and capital to work extra land".

Under "Contract 10", most of the means of production (machines, buffaloes, cattle and agricultural instruments) were recognized as the private owned. People could sell, purchase, or transfer these means in the market which were prohibited by the previous

\footnotetext{
5 The decline was also partly due to bad weather in these years.

${ }^{6}$ The first and second land are also called round 1 and round 2 by the farmers; the third fund called bidding.

"In most cases, capita "equivalent" means that an unit of this category is equivalent to a person in working ages or two persons over working ages or three children; some case it was accounted by coefficient.

${ }^{8}$ In fact, in many areas especially in the North the second land fund was also distributed cqually. The difference was only a higher "contact levels", because in Vietnam agricultural land per capita is very small.
} 
mechanism. Another point of this policy was that income of farmers has depended on how many stages they were responsible for but income could not be less than 40 percent of total producing output. This means that labor was transferred from hired labor to self-employment.

\section{Land Law (14 July 1993) and Ordinance 64/CP (27 Sep. 1993) of the Government about regulation on the allocation agricultural land to farm house- holds and individuals}

The main points of the Land Law were that it recognised that land is the property of the people, and as such is subject to exclusive administration by the State. The State shall allocate land to economic organizations, armed forces units, political social organizations, households and individuals for stable and long term use. Households and individuals are allocated land by the State from 5 use rights that are exchange, transfer, lease, heritage, and collateral. The duration of land allocation for stable and long term use for planting of annual crops and aquaculture was 20 years and for perennial crops was 50 years. The land use right certificate shall be given to the land users.

In order to give more detailed regulations on agricultural land, the Government enacted the Ordinance 64/CP. Again, this policy confirmed that households and individuals are allocated agricultural land by the State for the stable and long term use for the purpose of agricultural production. Agricultural land is defined as agricultural land for planting annual crops; agricultural land for planting perennial crops; and land with water surface for aquacultural production. Receivers of land must use the land for the agreed purpose and within the stipulated time limit. Land allocated to households and individuals under this Regulation shall be official and shall be accompanied by the issuance of a certificate of the right to stable and long term use of land. The duration of agricultural land allocation for planting annual crops and for aquacultural production shall be 20 years and perennial crops shall be 50 years. The limit of agricultural land area allocated to each household in 17 provinces in the Mekong River Delta and the South shall not exceed three hectares and others shall not exceed two hectares. In respect of agricultural land for planting perennial crops, there is not exceed 10 hectares in communes with flat field and 30 hectares in midland or mountainous communes. Persons who are entitled to the allocation of agricultural land for stable and long-term use shall be the local permanent residents, including those currently serving military duties.

\section{Other policies concerning to agricultural and rural development}

There are also other important policies that also contributed to agricultural and rural development in general and land use in particular as following:

- Ordinance No. 14/CP of the Government dated 2 March 1993 for providing credits to farm households.

- Laws on agricultural land use tax (24 July 1993); tax of transfer of agricultural land use rights (5 July 1994); and additional tax on households using over the limit of agricultural land (8 August 1994).

- The Regreening the barren hills Program (Program 327) launched in 1993.

- Ordinance No. $02 / \mathrm{CP}$ of the Government dated 15 January 1994 on the enactment of the regulations on the allocation of forestry land to organizations, households 
and individuals for stable and long term use for forestry purposes.

- Decision No. 773 TTg of the Prime Minister dated 21 December 1994 of the program on exploitation and use of wild land, river and coastal banks, and water surfaces in plain areas.

- New Cooperatives Law dated 1 January 1997.

- Decision No. 661/QD-TTg of the Prime Minister dated 29 July 1998 on the task; target; and implementation of the Five Million Hectare Reforestation Program (Program 661).

- Instruction No. 658 TTg of the Prime Minister dated 20 August 1997 on encouragement of equitization (privatization) of State-owned Farm enterprises.

- Instruction No. 10/CT-TTg of the Prime Minister dated 20 February 1998 on the encouragement and complete of land allocation; certificates of agricultural land use rights.

- National target Program for Hunger Eradication and Poverty Reduction (1998-2000) launched in July 1998 (Program 133).

- Decision No. 135/1998/QD-TTg of the Prime Minister dated 31 July 1998 on the approval of the socio-economic development program for especially difficult mountainous and remote communes (Program 135) known as the 1,715 Poor Communes Program (1998-2005).

- Revised Land Law dated 22 December 1998.

- Ordinance No. 17/ND-CP of the Government dated 29 March 1999 on the procedure of exchange; transfer; lease, release; heritage land use rights; and collateral (mortgage) or joining capital by using value of land use rights.

\section{ACHIEVEMENTS OF AGRICULTURE IN THE LAST TWO DECADES}

\section{The period after Decree No. 100 (1981-1988)}

After the reunification of the country in 1975, Vietnam's economy in general and agriculture in particular were facing with many difficulties. Moreover, some economic policies in that time were not sufficent enough to allow the economy to recover. The Net Material Product (NMP) ${ }^{9}$ decreased by 2.0 and 1.3 percent in 1979 and 1980, respectively (ADB, 1993, table 12, cited by Vali Jamal and Karel Jansen, 1998). Meanwhile, agriculture increased annually by very low rate of 2.03 percent in the period of 1976-80. The Decree 100 ("Contract 100") was the first sudden attack on the centrally bureaucratic management mechanism. It was considered as a "golden key" to open a new era of agricultural production in Vietnam (Nguyen Sinh Cuc, 1995). The total agricultural output increased annually by 6.57 percent in the period of 1981-85. The most visible progress was recorded in food production which increased by 5.86 percent from 14.4 million tons in 1980 to 17.8 million tons in 1984 and 18.2 million tons in 1985 . Rice sector output increased by 7.69 percent from 11.6 million tons in 1980 to 15.5 million tons in 1984 and 15.87 million tons in 1985 . Some crops have been grown significantly such as

\footnotetext{
${ }^{9}$ At that time, Vietnam was still under centrally-planted economy, so the most important macroeconomic indicator was Net Material Product (NMP) or National Income. The new GDP indicator has been used officially since 1993.
} 
sugarcane 18.32 percent; peanuts 15.97 percent; soybean 7.96 percent annually in the said period. If we compare two periods of 1981-85 and 1975-80, most of the indicators of agriculture increased with remarkable growth rates such as food production by 27 percent (of which rice 32 percent); buffalo herd 8 percent; ox herd 33 percent; and pig herd 22 percent. The survey of "product contract" carried out by General Statistical Office (GSO) at that time also showed that on average in each crop, 80 percent of farm households fulfilled and surpassed their signed contracts with an increase in real output from 5 to 20 percent over the contracted one (Nguyen Sinh Cuc, 1995). Thus, we can say that the first reform in agriculture had positive impacts on agricultural production and of course on the national economy ${ }^{10}$.

Table 1. Agricultural production in the period of 1981-1985

\begin{tabular}{|c|c|c|c|}
\hline Items & Unit & $\begin{array}{c}\text { Average annually } \\
1981-1985\end{array}$ & $\begin{array}{c}\text { Comparison of } \\
1981-1985 \text { to } \\
1975-1980(\%)\end{array}$ \\
\hline Food production (paddy equivalent) & million tons & 16.9 & 127 \\
\hline Of which: rice & million tons & 14.5 & 132 \\
\hline Average yield of rice per crop & $\mathrm{kg} / \mathrm{ha}$ & 2425 & 123 \\
\hline Food per capita & $\mathrm{kg} /$ person & 295.5 & 114 \\
\hline Buffalo herd & million heads & 2.5 & 108 \\
\hline Ox herd & million heads & 2.1 & 133 \\
\hline Pig herd & million heads & 11.2 & 122 \\
\hline \multicolumn{4}{|c|}{ Annual average growth rates of agriculture ${ }^{a}$} \\
\hline $1976-1980$ & $\%$ & \multicolumn{2}{|r|}{2.03} \\
\hline 1981-1985 & $\%$ & \multicolumn{2}{|r|}{6.57} \\
\hline
\end{tabular}

Source: Nguyen Sinh Cuc, 1995.

a. Vali Jamal and Karel Jansen, 1998

However, results gained under "Contract 100" were not sustainable. After 1985, agricultural production was declining. The overall growth rate of total agriculture in the period of 1985-88 was only 2.40 percent annually. In 1987 , food production decreased to 17.56 million tons (lower than 1984 level), and rice production also decreased to 15.1 million tons. During this period gross outputs of most of the crops increased with very low rates at that period such as rice with 2.31 percent growth; sugarcane 0.83 percent; peanuts 1.67 percent; soybean 2.59 percent; rubber 1.24 percent per year on average. Agricultural production in the whole country was subject to further stagnation and crisis. Overall the national economy was also in stagnation at that time. For example, annual growth rates of the Net Material Product decreased to 3.3 percent in 1987; 4.6 percent in 1988 and grew only 2.7 percent in 1989. This decline in growth rate was

${ }^{10}$ The Net Material Product (NMP) increased from $2.2 \%$ in 1981 to $8.9 \%$ in $1982 ; 7.2 \%$ in $1983 ; 8.3 \%$ in 1984; and 6.5\% in 1986 (ADB, 1993, table 12, cited by Vali Jamal and Karel Jansen, 1998).

"Other main reasons were an unsuitable policy promulgated in September 1985 called the Price, Salary, and Monetary Policy and about 1.5 million people were added each year at that time. 
partly attributed to unfavorable weather, but mainly to the invalidity of initial driving force by this policy ${ }^{11}$, because NMP of agriculture occupied almost haft of total NMP. In the North Vietnam, results were that agricultural supply did not meet demand leading to a starvation in 21 provinces and cities in early 1988 . The starvation has beaten 9.3 million people accounting for 39.7 percent of farm households, of which 3.6 million people were subject to very serious starvation. In the South, a series of new contradictions, especially in relation to land relations caused by "equally" land adjustment, arose in rural areas.

Some researchers have pointed out the disadvantages of this system such as eliminating farmers' motivation in decision making; cumbrous management of cooperatives was very cumbrous; farmers enjoining more on working points but not on working results. Other weaknesses were also pointed out by Pingali and Vo Tong Xuan (1992) are as follows (1) land use and crop choice decisions were still done by the State Planning Commission without consideration of farmers preferences and local market conditions; (2) seasonal surpluses at the farm gate led to a crash in the private rice price in several regions, which while benefiting the urban poor had severe incentive effects on farmers; (3) the persistence of centralized input supplies resulted in inadequate and untimely provision of inputs to farmers; and (4) lack of security of land tenure resulted in inadequate farm level investments for maintaining long-term land productivity (cited by Soushun Nakachi, 1999).

As showed above, the process of reform in this period was hesitant and inconsistent. It gave limited freedom to agricultural cooperatives and farmers because there were no other supplemented policies that were synchronous, consistent, and adequate with "Contract 100". In 1986, the Communist Party of Vietnam worked out socio-economic renovation policies that have changed not only agriculture but also the economy and society as a whole.

Table 2. Annual growth rates of agriculture in the period of 1989-1999

\begin{tabular}{|c|c|c|c|c|}
\hline \multirow{2}{*}{$\begin{array}{l}\text { Years/ } \\
\text { Period }\end{array}$} & \multirow{2}{*}{$\begin{array}{c}\text { Total } \\
\text { agriculture }\end{array}$} & \multicolumn{3}{|c|}{ Of which: } \\
\hline & & Cultivation & Livestock & Services \\
\hline 1990 & 101.8 & 101.5 & 103.0 & 101.0 \\
\hline 1991 & 102.9 & 103.7 & 100.1 & 102.8 \\
\hline 1992 & 108.4 & 107.1 & 112.8 & 108.3 \\
\hline 1993 & 106.7 & 106.9 & 105.6 & 107.2 \\
\hline 1994 & 104.9 & 104.7 & 105.4 & 106.2 \\
\hline 1995 & 106.6 & 107.1 & 104.5 & 108.4 \\
\hline 1996 & 105.1 & 105.2 & 105.3 & 101.1 \\
\hline 1997 & 107.0 & 107.0 & 107.8 & 102.0 \\
\hline 1998 & 103.6 & 103.5 & 104.8 & 101.1 \\
\hline 1999 & 107.1 & 107.2 & 106.8 & 103.8 \\
\hline \multicolumn{5}{|c|}{ Average Annual Growth Rates: } \\
\hline $89-93$ & 4.92 & 4.77 & 5.27 & 4.78 \\
\hline $94-99$ & 5.71 & 5.77 & 5.76 & 3.73 \\
\hline
\end{tabular}

Note: Previous year $=100 \%$

Sources: Vietnam Statistical Yearbook, various years. 


\section{The period after Resolution No. 10 (1989-1993)}

Since the renovation policy was promulgated in 1986 and the situation of agriculture that happened in 1986-87, the Politburo enacted Resolution 10 on the renovation of agricultural economic management. This was a radical reform in agriculture. There were four important elements in this policy: Land rights; introduction of the market mechanism; liberation of prices; and demise of the collectives. These are the main factors that mobilized farmers to use more efficient production resources more efficiently and to liberate all production forces. Since then, Vietnam's agriculture has entered a new and relatively more stable development stage. In the period of 1989-93, the total agricultural output increased by 4.92 percent annually, of which cultivation, livestock, and services increased annually by $4.77,5.27$, and 4.78 percent, respectively. The greatest achievement was recorded in 1992, when the growth rates of three sub-sectors in agriculture were in turn 7.1, 12.8, and 8.3 percent, respectively in comparison with previous year (1991). Gross paddy equivalent food output, paddy yield, food per capita, buffalo herds, and ox herds during 1989-92 increased by 4.6 million tons (26.1 percent), $450 \mathrm{~kg} / \mathrm{ha}$ (29.6 percent), $36 \mathrm{~kg}$ (12.2 percent), $10.8 \%, 14.8 \%$, and 19.8 percent, respectively over those during 1981-88 (Nguyen Sinh Cuc, 1995).

The food and food stuff situation in the whole country became more stable than at any time before. Food production increased annually by 4.34 percent from 21.5 million tons in 1989 to 25.5 million tons in 1993 . The rice sector contributed mainly in food sub-sector achievement. It increased annually by 4.71 percent from 19 million tons in 1989 to 22.8 million tons in 1993 . Food per capita reached a record of $359 \mathrm{~kg}$ per person in 1993. In 1989, for the first time Vietnam become a net exporter of rice. The rice export volume increased from 1.42 million tons in 1989 to 1.946 million tons (an increase of 37.04 percent) in 1992 and 1.722 million tons (an increase of 21.27 percent) in 1993.

Together with significant development recorded in food production, outputs of non-rice crops especially industrial crops also have changed positively. Coffee, rubber, soybean, peanuts, and sugarcane had increased by $35.06 \%, 17.64 \%, 6.55 \%, 5.97 \%$, and 3.29 percent annually, respectively in the said period. Export of the above crop products also changed with an increasing trend. The highest increase was recorded in peanut export with growth rate of 169.23 percent in this period from 39,000tons in 1989 to 105,000 tons in 1993. Coffee was the second with an increase of 85.96 percent from 57,000 tons in 1989 to 106,000 tons in 1993. Total export value of agricultural, forestry, and aquacultural products in 1992 climbed up to US $\$ 1.276$ billion from US $\$ 1$ billion in 1989 (Nguyen Sinh Cuc, 1995). Export values of the main four crop products (rice, coffee, rubber, and tea) increased by 81.90 percent in three years from US $\$ 315$ million in 1990 to US\$ 573 million in 1993 (authors calculation from World Bank Statistical Data).

The other great achievement of agriculture in the said period is agricultural diversification, which illustrated an important aspect of the dynamics of agrarian change. The diversification is reflected firstly by the change from domestic to export markets and the secondly in terms of the crop mix. The data about agricultural exports showed the first aspect. Phenomenal progress is evinced, most striking being the case of rice and coffee. Before 1989, Vietnam was a net importer of rice, but immediately after the Resolution 10 a large surplus appeared and Vietnam exported more than 1 million tons of rice. This has been an increasing trend and Vietnam is now one of the major suppliers of rice on the 
Table 3. Gross outputs of some crops and average annual growth rates

(Unit: '000 tons; \%)

\begin{tabular}{|c|c|c|c|c|c|c|c|c|}
\hline \multirow[b]{2}{*}{$\begin{array}{l}\text { Years/ } \\
\text { Period }\end{array}$} & \multicolumn{2}{|c|}{ Food crops ('000 tons) } & \multirow{2}{*}{$\begin{array}{l}\text { Paddy } \\
\text { per } \\
\text { capita } \\
\text { (kg) }\end{array}$} & \multirow[b]{2}{*}{ Sugarcane } & \multirow[b]{2}{*}{ Peanuts } & \multirow[b]{2}{*}{$\begin{array}{l}\text { Soybean } \\
\text { ('000 tons) }\end{array}$} & \multirow[b]{2}{*}{ Coffee } & \multirow[b]{2}{*}{ Rubber } \\
\hline & Total & $\begin{array}{l}\text { Of which: } \\
\text { rice }\end{array}$ & & & & & & \\
\hline 1980 & $14,406.4$ & $11,647.4$ & 268.2 & $4,358.9$ & 95.2 & 32.1 & 8.4 & 41.0 \\
\hline 1981 & $15,005.2$ & $12,415.2$ & 273.2 & $3,964.4$ & 106.3 & 55.0 & 4.6 & 43.6 \\
\hline 1982 & $16,828.8$ & $14,390.2$ & 299.6 & $4,576.9$ & 119.0 & 76.8 & 4.6 & 46.0 \\
\hline 1983 & $17,185.8$ & $14,743.3$ & 296.1 & $5,689.5$ & 126.3 & 63.6 & 5.0 & 47.2 \\
\hline 1984 & $17,800.0$ & $15,505.6$ & 303.5 & $6,566.6$ & 165.8 & 69.2 & 4.1 & 47.2 \\
\hline 1985 & $18,200.0$ & $15,874.8$ & 304.2 & $5,559.7$ & 202.5 & 79.0 & 12.3 & 47.9 \\
\hline 1986 & $18,379.1$ & $16,002.9$ & 300.8 & $4,966.2$ & 210.3 & 84.7 & 18.8 & 50.0 \\
\hline 1987 & $17,562.6$ & $15,102.6$ & 281.2 & $5,467.2$ & 230.0 & 95.8 & 20.5 & 51.7 \\
\hline 1988 & $19,583.1$ & $17,000.0$ & 307.3 & $5,699.4$ & 212.8 & 85.3 & 31.3 & 49.7 \\
\hline 1989 & $21,515.6$ & $18,996.3$ & 332.2 & $5,344.6$ & 205.6 & 82.0 & 40.9 & 50.6 \\
\hline 1990 & $21,488.5$ & $19,225.2$ & 324.4 & $5,405.5$ & 212.8 & 86.6 & 92.0 & 57.9 \\
\hline 1991 & $21,989.5$ & $19,621.9$ & 324.9 & $6,162.5$ & 235.3 & 80.0 & 100.0 & 64.6 \\
\hline 1992 & $24,214.6$ & $21,590.3$ & 348.9 & $6,437.0$ & 226.7 & 80.1 & 119.2 & 67.0 \\
\hline 1993 & $25,501.7$ & $22,836.6$ & 359.0 & $6,082.7$ & 259.3 & 105.7 & 136.1 & 96.9 \\
\hline 1994 & $26,198.5$ & $23,528.2$ & 360.9 & $7,750.1$ & 294.4 & 124.5 & 180.0 & 128.8 \\
\hline 1995 & $27,570.9$ & $24,963.7$ & 372.8 & $10,711.1$ & 334.5 & 125.5 & 218.1 & 124.7 \\
\hline 1996 & $29,217.8$ & $26,396.7$ & 387.7 & $11,430.3$ & 357.7 & 113.8 & 316.9 & 142.5 \\
\hline 1997 & $30,618.1$ & $27,523.9$ & 399.1 & $11,920.9$ & 351.3 & 113.0 & 420.5 & 186.5 \\
\hline 1998 & $31,853.9$ & $29,141.7$ & 407.9 & $13,843.5$ & 386.0 & 141.3 & 409.3 & 225.7 \\
\hline 1999 & $34,000.0$ & $31,000.0$ & $445.6^{*}$ & $\cdots$ & $\cdots$ & $\cdots$ & $\ldots$ & $\ldots$ \\
\hline \multicolumn{9}{|c|}{ Annual growth rates $(\%)$ : } \\
\hline $81-85$ & 5.86 & 7.69 & 3.57 & 18.32 & 15.97 & 7.96 & -3.76 & 2.68 \\
\hline $85-88$ & 2.47 & 2.31 & 0.34 & 0.83 & 1.67 & 2.59 & 36.53 & 1.24 \\
\hline $89-93$ & 4.34 & 4.71 & 1.96 & 3.29 & 5.97 & 6.55 & 35.06 & 17.64 \\
\hline $94-98$ & 5.01 & 5.49 & 3.11 & 15.61 & 7.01 & 3.22 & 22.80 & 15.05 \\
\hline $94-99$ & 5.35 & 5.67 & $4.31^{*}$ & & & & & \\
\hline
\end{tabular}

Note: * Number computed based on the data of population census in 1999 .

Sources: Vietnam Statistical Yearbook, various years.

WB Vietnam, 2000 (for data in 1999).

world market. Coffee turned from a minority crop in the 1980s to an important export product. In 1993, export volume of coffee was 4 times higher than that in 1988. Exports of aquacultural products also increased three times between 1988 and 1993 (from 21,000 tons in 1988 to 63,000 tons in 1993).

As for the diversification of the production base, by 1993 the sown areas under annual crops had fallen to 89.13 percent from 90.05 percent in 1988. The share of sown area under vegetables and beans increased from 5 percent in 1988 to 5.35 percent in 1993 . The share of areas under sown perennial crops also increased from 9.95 percent in 1988 to 10.87 percent in 1993 . The sown areas under long-life industrial crops (coffee, rubber, etc.) and vegetables and beans increased with the highest annual growth rates of 4.39 percent and 3.47 percent, respectively. Meanwhile, average annual growth rate of sown 
areas of all crops was 2.35 percent.

A certain progress of diversification was also recorded in terms of crop values. The share of food crop product value in 1989 and 1992 was 67.6 percent and 62.1 percent, respectively. These figures of industrial crops and fruit trees were $14.1 \%, 15.4 \%$ and $8.25 \%$ and 9.14 percent, respectively (Nguyen Sinh Cuc, 1995). The changes in different regions were not the same. In the delta and suburb of big cities, farmers' prefered to cultivate higher value added crops and in the midland areas where more land available farmers wanted to develop fruit trees.

Other achievement of agriculture in this period was the increase in farmers' income. Results of the two surveys of rural areas conducted by General Statistical Office and the Ministry of Agriculture in 1989 and 1992 showed the positive status and increasing income tendency of rich and poor farm households in rural areas. The proportion of rich households in rural areas in rural areas increased from 8.08 percent in 1990 to 9.7 percent in 1991 and 15 percent in 1992 and their rich level also climbed up, while the proportion of poor households dropped from 20 percent in 1990 to 15 percent in 1992 (Nguyen Sinh Cuc, 1995). Achievements recorded in agricultural production and the rural economy largely contributed a decisive part to gradually pulling the economy out of crisis and finding out a new development direction. Farmers' intellectual and material life was much more improved than that before the introduction of the Resolution 10.

However, there existed some contradictions and constraints. One of the biggest contradictions that arose in rural areas was regarding land relation ${ }^{12}$ : the relation of multi-plot allocation of agricultural land and requirement for concentrating land towards commercial production particularly in the North. In the northern delta, on average a household was assigned five to seven contracted land plots on different fields, which were small and caused difficulties for application of technology (mechanization, irrigation, etc.). Division of contracted land stock into three funds/rounds (round 1, round 2, and bidding) also created difficulties in management of cooperatives. Rich and poor farmers (with very different conditions) were still assigned contracted land "equally" and capital, experience and labor potential of two types of households were different, so it not improve land and crop productivity.

\section{The period after Land Law and the Ordinance 64/CP (1994 onwards)}

This period was started with the Resolution No. 5 of the Central Committee of the Party that was supplemented by other important policies developed agriculture as well as rural areas such as Ordinance No. 14/CP on providing credits to farm households; Ordinance No. $13 / \mathrm{CP}$ on agricultural extension; Ordinance No. $02 / \mathrm{CP}$ on allocation of forestry land for stable and long term use; the Greening the Barren Hills Program (Program 327); Program for Hunger Eradication and Poverty Reduction (Program 133); the Socio-economic Development Program for Especially Difficult Mountainous and

\footnotetext{
12 Other contradictions pointed out by Nguyen Sinh Cuc (1995) are as follows (a) this system was not significant in the South (because cooperatives and production groups are formalistic, land use right and land ownership are considered the same); (b) paddy fields and areas under annual crops decreased; (c) contradiction between labors, land, employment, and income in rural areas; (d) requirements for commercial production and poor rural infrastructure; and (e) increasing agricultural production and declining processing
} 
Remote Communes (Program 135); and Five Million Hectares Reforestation Program (Program 661) of the Government; etc.

This period was also characterized with more stable development than any time before. The total agricultural output grew at an annual average of 5.71 percent between 1994 and 1999, of which cultivation, livestock, and services increased annually in turn of $5.77 ; 5.76$; and 3.73 percent, respectively. The growth rates ranged from 3.6 percent to 7.1 percent. In 1998, the lowest growth rate was observed at 3.6 percent and the next year it was highest at 7.1 percent. Throughout this period the development of agriculture was even more stable than any other industries.

The food situation in the whole country has been conisiderably improved. Total food output increased annual average by 5.35 percent from 26.20 million tons in 1994 to 34 million tons in 1999, of which rice grew at an annual average of 5.67 percent from 23.5 million tons in 1994 to 31 million tons in 1999. The paddy equivalent per capita also reached a record of $445 \mathrm{~kg} /$ person (in 1999). In this period, food production increased by 2 million tons each year. Results of the food sector have contributed to the achievement of food security at the aggregate level ${ }^{13}$.

Outputs of other crops especially industrial crops have also increased significantly. Coffee production increased by 22.80 percent from 180,000 tons in 1994 to 409,300 tons in 1998. Sugarcane grew at an annual average of 15.61 percent from 7.75 million tons in

Table 4. Outputs of vegetables, fruits and livestock sector

\begin{tabular}{|c|c|c|c|c|c|}
\hline & 1995 & 1996 & 1997 & 1998 & $\begin{array}{l}\text { Annual } \\
\text { growth } \\
\text { rate (\%) }\end{array}$ \\
\hline $\begin{array}{l}\text { Vegetables (total country, '000 tons) } \\
\text { Of which: }\end{array}$ & $4,186.0$ & $4,706.9$ & $4,969.9$ & $5,150.0$ & 7.15 \\
\hline Red River Delta & $1,231.0$ & $1,582.5$ & $1,597.9$ & $1,657.9$ & 10.43 \\
\hline Mekong Delta & 949.7 & 958.3 & 964.5 & $1,062.0$ & 3.80 \\
\hline \multicolumn{6}{|l|}{ Fruit sub-sector ('000 tons) } \\
\hline Longan, Lichi, and Rambutan & 223.3 & 289.9 & 405.2 & 397.1 & 21.16 \\
\hline Bananas & $1,061.2$ & $1,263.0$ & $1,316.1$ & $1,315.2$ & 7.42 \\
\hline \multicolumn{6}{|l|}{ Livestock (live-weight, '000 tons). } \\
\hline Buffaloes & 37.33 & 49.29 & 50.86 & 44.60 & 6.11 \\
\hline Cattle & 64.55 & 70.07 & 71.80 & 83.15 & 8.81 \\
\hline Pigs & $1,011.4$ & $1,080.0$ & $1,154.2$ & $1,228.0$ & 6.68 \\
\hline Poultry & 196.7 & 213.0 & 226.1 & 239.2 & 6.74 \\
\hline Eggs (mill. eggs) & 2.66 & 3.08 & 3.17 & 3.23 & 6.57 \\
\hline
\end{tabular}

Sources: Vietnam Statistical Yearbook, 1999.

\footnotetext{
${ }^{13}$ The export rice quotas will be removed by the next year (2001). In November 2000, the Government has set up a new poverty line which will apply for the period of 2001-2005, but not food poverty line (for the hungry criteria) as before.

${ }^{14}$ An increase in sugarcane production was partly due to the One Million Tons of Sugar Program of the Government.
} 
1994 to 13.84 million tons in 1998. In 1998, the output level of coffee was ten times higher than that in $1989^{14}$. The annual average growth rate of rubber output was 15.05 percent increasing from 128,800 tons in 1994 to 225,700 tons in 1998. Other industrial crops such as peanuts and soybean grew at an annual average of 7.01 and 3.22 percent, respectively.

In this period, farmers shifted production towards cash crops such as vegetables. Over the whole country, gross output of all kinds of vegetables reached threshold of 5 million tons in 1998. It grew at an annual average of 7.15 percent from 4.186 million tons in 1995 to 5.15 million tons in 1998. Outputs of fruits have also increased significantly. An annual average growth rate of output of only three kinds of fruits as longan, lichi, and rambutan was 21.16 percent in the period of 1995-98 (from 223,273 tons in 1995 to almost 400,000 tons in 1998). Production of bananas increased from 1.06 million tons in 1995 to 1.32 million tons in 1998 (7.42 percent increased).

This success was due to both expansion (labor and land) and intensification measures. After land allocation, farmers become real owners of land (use owners). As a result they paid more attention and invested more labor in their land. In the last period (1994-98), the total areas sown grew at an annual average of 3.24 percent annually from $10,172.4$ thousand hectares to $11,704.8$ thousand hectares. The annual average growth rate of areas sown under perennial crops $^{15}$ was highest of 9.32 percent from $1,171.9$ thousand hectares in 1994 to $1,693.5$ thousand hectares in 1998, of which areas of industrial and fruit crops grew at an annual average of 9.69 and 8.17 percent, respectively. In an annual crop group, areas sown to food crops have increased with a slow average rate (only 1.84 percent annually), while areas under annual industrial crops and vegetables and beans have increased at a faster rate of 6.18 and 5.56 percent, respectively. In 1998, sown areas of annual industrial crops and vegetables and beans have reached 808,200 and 623,100 hectares, respectively. Although growing at a slow average rate, the sown areas of food crops reached a record of $8,540,600$ hectares in 1998, of which rice areas accounted for 85.31 percent $(7,362,400$ hectares). In term of each crop, cultivated areas of coffee grew fastest of 31.51 percent from 123,900 hectares in 1994 to 370,600 hectares in 1998. The second crop was sugarcane of an annual average growth rate of 14.16 percent and reached 283 thousand hectares in 1998. The third crop that had a high annual growth rate was rubber (average of 10.82 percent). Sown areas of rubber increased from 258,400 hectares in 1994 to 389,800 hectares in 1998 .

Besides that, crop yields in this period have also improved. The yield of spring rice grew at an annual average of 3.21 percent from 4.43 tons/ha in 1995 to 4.87 tons/ha in 1998 , the highest was recorded in the Red River Delta at 5.50 percent from 4.71 tons/ha in 1995 to 5.53 tons/ha in 1998 . Winter rice yield also had a similar situation. Across the whole country, it increased at an annual average of 3.80 percent from 2.96 tons/ha in 1995 to 3.31 tons/ha in 1998. Winter rice yield of the Red River Delta was also highest. It increased from 4.17 tons/ha in 1995 to 4.73 tons/ha in 1998 (4.29 percent increased). Other annual industrial crops had similar scenarios. Soybean yield increased from 1.04 tons/ha in 1995 to 1.11 tons/ha in 1998 (2.20 percent increased). Peanut yield grew

\footnotetext{
${ }^{15}$ Including two groups of multiyear industrial crops (coffee, rubber, tea, etc.) and fruit crops.

${ }^{16}$ In Vietnam, an important indicator of animal (pig, poultry, cattle, and buffaloes) production output is live-weight.
} 
at an annual average of 3.49 percent from 1.29 tons/ha in 1995 to 1.43 tons/ha in 1998 .

One interesting feature of agricultural development in this period is the steadily increasing share of animal husbandry, mainly household-based, in total output. Its development is also more stable in comparison with the cultivation sector. Output of livestock grew at an annual average of 5.76 percent annually between 1994 and 1999 . One of the most important sub-sector of animal husbandry is pig production. Pigs live--weight $t^{16}$ increased from 1.01 million tons in 1995 to 1.23 million tons in 1998 (6.68 percent increased). Cattle live-weight also increased significantly from 64,548 tons in 1995 to 83,154 ton in 1998 or increased by 8.81 percent in the said period. Poultry production output, both live-weight and eggs also had a good result. Poultry live-weight grew at an annual average of 6.74 percent from 196,700 tons in 1995 to 239,200 tons in 1998 and number of eggs increased from 2.66 million in 1995 to 3.23 million in 1998 (6.57 percent increased).

Another achievement of agriculture is export performance. In the period (1994-99), export of agricultural products was more stable and significant than at any time before. Rice export grew at an annual average of 17.85 percent from 1.983 million tons in 1994 to

Table 5. Exports of main agricultural products

\begin{tabular}{|c|c|c|c|c|c|c|c|c|}
\hline \multirow{2}{*}{ Year } & \multirow{2}{*}{ Rice } & \multirow{2}{*}{ Coffee } & \multirow{2}{*}{$\begin{array}{l}\text { Rubber } \\
\text { ('000 tons) }\end{array}$} & \multirow{2}{*}{ Tea } & \multirow{2}{*}{ Peanuts } & \multirow{2}{*}{$\begin{array}{l}\text { Vegetables } \\
\text { and fruits } \\
\text { (mil. US\$) }\end{array}$} & \multicolumn{2}{|c|}{ Aquatic \& seafood products } \\
\hline & & & & & & & $\begin{array}{c}\text { Quantity } \\
\text { ('000 tons) }\end{array}$ & $\begin{array}{c}\text { Value } \\
\text { (mill. US\$) }\end{array}$ \\
\hline 1980 & 33 & 4 & 33 & & 8 & & & \\
\hline 1985 & 59 & 9 & 35 & 10 & 31 & & 10 & \\
\hline 1986 & 125 & 19 & 37 & 11 & $\mathrm{n} / \mathrm{a}$ & & 12 & \\
\hline 1987 & 120 & 21 & 35 & 12 & $\mathrm{n} / \mathrm{a}$ & & 13 & \\
\hline 1988 & 87 & 25 & 38 & 15 & $\mathrm{n} / \mathrm{a}$ & & 21 & \\
\hline 1989 & 1,420 & 57 & 58 & 15 & 39 & & 48 & \\
\hline 1990 & 1,624 & 90 & 76 & 16.1 & 71 & & 46 & \\
\hline 1991 & 1,033 & 94 & 63 & 8 & 79 & & 58 & 285.4 \\
\hline 1992 & 1,946 & 116 & 82 & 13 & 63 & & 63 & 307.6 \\
\hline 1993 & 1,722 & 106 & 97 & 21 & 105 & & 68 & 427.2 \\
\hline 1994 & 1,983 & 162 & 136 & 24 & 119 & & 84 & 489.0 \\
\hline 1995 & 1,998 & 248.1 & 138.1 & 18.8 & 111 & & 85 & 621.4 \\
\hline 1996 & 3,003 & 283.7 & 194.5 & 20.8 & 127 & & $\ldots$ & 696.5 \\
\hline 1997 & 3,553 & 389.3 & 194.6 & 32.2 & 83 & 68.258 & $\ldots$ & 781.0 \\
\hline 1998 & 3,800 & 379.0 & 185.0 & 34.0 & 87 & 53.392 & $\ldots$ & 850.0 \\
\hline 1999 & 4,508 & 482.5 & 265.3 & 36.4 & 55.5 & 104.922 & $\ldots$ & 951.1 \\
\hline $\begin{array}{c}\text { October } \\
2000\end{array}$ & 3,041 & 536 & $\ldots$ & $\ldots$ & $\ldots$ & $\ldots$ & $\ldots$ & $1,167.1$ \\
\hline
\end{tabular}

Sources: Vietnam Statistical Yearbook, various years.

General Department of Customs

Socio-Economic Statistical Bulletin. UNDP Vietnam, 2000.

\footnotetext{
"The other reason was that the two biggest importers of Vietnam's rice are Indonesia and the Philippines. Poor harvests and financial crisis led to high rice imports in 1998 and 1999. In 2000, these countries' rice import fell as their economies recovered and harvests improved.
} 
4.508 million tons in 1999. This result has transformed Vietnam to the second largest rice exporter in the world behind Thailand since 1996. In 1998 and 1999, foreign exchange earnings from the export of rice were surpassed the US $\$$ one billion threshold. However, over the past two years (1999 and 2000), the price of rice has fallen. This decline in the price of rice has led the Government to adopt measures to support the stockpiling of rice in 1999 and request exporter withhold shipment to wait for higher world prices (Decision 35/2000/QD-TTg, March 21, 2000). This explains the reason why up to the end of October of this year, the volume of rice export was only 3.041 million tons ${ }^{17}$.

The second most important agricultural product exported is coffee. The export of coffee has been increasingly encouraged. It grew at an annual average of 24.39 percent from 136,000 tons in 1994 to 482,500 tons in 1999. At the end of October 2000, coffee export volume reached 536,000 tons which increased by 11.09 percent in comparison with all the year of 1999. Export volumes of two other industrial crops as rubber and tea have also increased significantly. Rubber exports grew at an annual average of 14.30 percent, while tea grew at 8.69 percent per year between 1994 and 1999. Their volumes exported increased from 136,000 and 24,000 tons in 1994 to 265,300 tons and 36,400 tons in 1999 , respectively.

Despite good production of vegetables and fruits in the recent years, the quality and the standards of these products in Vietnam are still very low. Thus, export of these products is still modest. In two years (1997-99), foreign exchange earnings from the export of vegetables and fruits grew at an annual average of 8.98 percent and reached only US\$104.922 million in 1999 from US\$68.258 million in 1997.

Export of seafood and aquacultural products has become one of the three important non-oil exports (garments, footwear, and seafood and aquaculture). They grew at an impressive 14.23 percent over the past 5 years. Export earnings from these products increased from US\$ 489 million in 1994 to US\$ 951.1 million in 1999. At the end of October 2000, export earnings of aquaculture and seafood were surpassing a threshold of US $\$$ one billion (reached US\$ 1.17 billion).

Changes in trade policies also contribute to these results. Over the years, most export quotas have been lifted and export taxes have been reduced to generally low levels. In addition, export activities by the private sector (both domestic and foreign) have been increasingly encouraged, thus breaking the trade monopoly of a small number of state-owned enterprises. However, in 1999, the value of agricultural exports increased by only 5.6 percent. This modest performance is due to a decline in prices of Vietnam's most import agricultural exports, in particular rice and coffee (WB Vietnam, 2000) ${ }^{18}$. This decline in the price led farmers less fortunate with the recent changes in commodity prices.

\section{CONSTRAINTS AND CHALLENGES FACING AGRICULTURAL DEVELOPMENT}

Vietnam's agriculture has undergone big changes in the last two decades, particularly since the implementation of the Land Law (1993) and the Ordinance 64/CP on the allocation of agricultural land to farm households and individuals for stable and long term

\footnotetext{
${ }^{18}$ Agricultural prices recorded a 13.9 percent decline in 1999 (WB Vietnam, 2000).
} 
use. As a result, during the 1990s; agricultural production grew at an average of 5.39 percent; poverty has fallen from $25 \%$ in 1993 to $15 \%$ in 1998 and $11 \%$ in 2000 (MOLISA, 2000); and agricultural exports have increased significantly; etc. However, Vietnam is still faced with many difficulties nowadays. Agricultural growth has slowed and the prices of agricultural products have declined in the recent years. Poverty and malnutrition are still a phenomenon of rural areas. Unemployment and underemployment are still very high and off-farm opportunities are still lacking. Farm size, only 0.62 hectare on average (1998) is very small and provides only part time work for most families. In addition, land is very dispersed and scattered. The structure of agriculture has changed very slowly. After a decade, gross outputs of the three sub-sectors of agriculture (cultivation, livestock, and services) were almost the same as before. Output of cultivation was dominant (more than 80 percent) while output of services sector was less than 3 percent each year.

For further development and in the process of industrialization and modernization of agriculture and rural areas, difficulties and challenges of this industry must be considered by the Government and society. The most important challenges could be seen as follows:

+ Like all low income agricultural countries, agricultural technology and rural infrastructure are very poor, but there is few budget to support agriculture

Many studies based on economic theory have shown that farmers in Vietnam are poor but their production is efficient. Since the implementation of the reform policies, they have invested their own labors and inputs according to their capabilities. Technological change needs support and help from the Government and researchers, as farmers can not do themselves.

+ Rice is still a dominant crop in agriculture. When its price declines, it will affect the income of the two-thirds of the population

In the 1980s and beginning of $1990 \mathrm{~s}$, poverty especially food poverty was a common phenomenon in rural areas, dominant rice production and increase rice production are good solutions to overcome starvation and backwardness. However, rice is not a labor-intensive and high value added crop in Vietnam. The growth of the rice sector was an impressive and significant but farmers are still poor and underemployed. In fact, it is observed that communes producing much more rice even having higher yields are poorer than those producing less rice with lower yields (in delta regions).

+ The relative prices between manufactured and agricultural products are not good for farmers

Data recorded by the State Committee of Prices and UNDP Vietnam showed that during the seven years from December 1990 to December 1997 growth in the consumer price index (CPI) of agricultural products was lowest at 235.7 percent, while the CPI of processed products and services group increased by 353.3 and 337.7 percent, respectively. Besides that many goods produced by big state-owned enterprises are more expensive in rural areas. For example, farmers in rural areas have to pay for electricity at a higher price than those in urban areas. In the last two years, price of food have declined significantly in comparison with non-food products.

+ There are few private enterprises operating in agricultural and processing industries;

+ There is an imbalance between regions; and

+ The dramatic supply response following the sequential liberalization of 


\section{agriculture and other sectors is no longer available}

Before 1988-89, Vietnam was still under centrally-planned economy. This means that every business was under the control of the Government. In agriculture, farmers had no responsibility to make decisions such as what crops to grow; what levels of inputs and outputs should be considered. Great results of the reforms were partly due to the unleashing of farmer energies. Farmers advanced from being hired labors to being self-employment and became decision makers of their production. However, the effects of this process will no longer be available in the coming years.

\section{CONCLUSION AND POLICY IMPLICATION}

The great achievement of agriculture due to reform policies are undeniable. These policies have led to big changes not only in the agricultural and rural sector but also in the national economy and in society as a whole. The first reform started in 1981 with a shift of responsibility for cultivation to farming household. Although the shift was only partial, this reform helped to unleash farmers, and output and efficiency responded significantly. The 1988-89 reforms swept away ambiguities: production means and other goods were returned to private ownership, production and distribution were liberalized, price control abolished. In addition, liberalization of external trade and devaluation of the currency opened up the economy to the world market. The effects of reform policies are continuing to be felt up today and in the future. This analysis has shown that along with the yields, total output of agriculture increased dramatically. This led to a more efficient use of land, the scarcest production factor in Vietnam. Agricultural and rural incomes have also improved and rural poverty has fallen. However, poverty is still a phenomenon of rural areas and ethnic minority groups. In recent years, agricultural productivity growth has been slow; income disparities between regions and groups of people have widened; and unemployment and underemployment in rural areas is now more severe.

In the future, the policy meeting the strategy for a Vietnam to have an economy with sustainable and rapid development and stable society with a high quality of life for all of its people needs consistent and synchronous policies. The kinds of policy changes required to promote a new round of growth including technical, political, and social areas will be more difficult than those of the first round of "Doi Moi".

\section{COMING POLICIES SHOULD BE ADDRESSED IN THE FOLLOWING FIELDS:}

\section{Intensifying agricultural production}

The successful growth of agricultural production during the last decade was largely due to increased labor and capital inputs, which when combined accounted for 87 percent of the growth. Land expansion accounted for 9 percent of the gains, and technology improvement only 4 percent. Meanwhile, Vietnam spent only 1.7 percent of its public agricultural budget on research in comparison with 6 percent in China and 10 percent in Malaysia and Thailand (Andrew Steer et al., 2000). Yields of most of the crops nave improved in the last decade, however, they are still lower than that of other countries in

the region. For example, Vietnam's rice yields are still below China's. This offers scope for further gains. In the coming years, the role of technological change should be 
addressed. This will require more attention to research and information dissemination. In the agricultural sector, new varieties are more important and will play a deciding role in future agricultural development. In Vietnam, state-owned farm enterprises still exist. It will be necessary to orient them towards research and extension in opening up supply industries, especially seeds production.

\section{Diversifying agriculture}

One of the targets of the Ten-Year Socio-Economic Development Plan drafted by the Government in 2000 is to double the average agricultural product to the US\$2,000 per hectare in the next ten years. However, cultivated areas of rice and food crops are still dominant. Rice accounted for over 60 percent of total sown areas (64.45 percent in 1995 and 62.90 percent in 1998). Areas of food crops accounted for 75.95 percent and 72.97 percent in two years 1995 and 1998, respectively. Moreover, food prices are trending downwords. Despite an official policy supporting diversification, there remain other inconsistent documents, and local and historical pressure ${ }^{19}$ to produce rice and food. Vietnam is located in the tropical region, where huge opportunities exist for higher value added crops. In order to encourage diversification of agriculture, measures such as following schould be encouraged:

- Give farmers as much technological and market information as possible in a comprehensive form;

- Accelerate and complete the process of issuing land certificates; to encourage farmers to exchange agricultural land between each other and to accelerate the land consolidation process; and to allow farmers access to credits by using collateral land right; and

- Promote the private sector, especially in the food processing industry in rural areas.

\section{Encouragement of off-farm activities}

One of the biggest challenges to Vietnam's agriculture is small farm size and high rates of unemployment and underemployment of the agricultural labor force. In every country that has successfully modernized labor has been drawn out of agriculture into higher value adding industries (WB Vietnam, 2000). Such transition will be more important in Vietnam because Vietnam has been implementing the policy of industrialization and modernization of the whole economy and if farmers are to enjoy the same income gains as the population as a whole, the number of workers in agriculture will need to fall significantly over the decade. Besides that, Vietnam has to consider about 1.2-1.3 million people entering the labor force each year and most of them in rural areas. Thus, promoting the private small and medium enterprises (SMEs) is very important and necessary in the coming years. Vietnam has promulgated the Enterprise Law which led to the registration of more than 10,000 additional domestic firms in the first nine months of 2000. However, domestic firms still number less than 30,000 and produce well under $10 \%$ of GDP (Andrew Steer et al., 2000). Handicraft, rural industries and services should be

\footnotetext{
:9 Before ten years (1988), all rural people in the North were under serious starvation/hungry, that' why farmers are still thinking and avoiding that situation.
} 
considered and addressed by the policy makers.

\section{Increasing domestic demand for agricultural products}

Vietnam with a population of 76.3 million and 76.5 percent of them living in rural areas is big market for agricultural products and services. However, most are farmers and have low incomes. Thus, their purchasing power is also low (in some cases farmers-producers of high value added (off-season) vegetables are afraid to consume products produced by them. Their preferences are to sell them to get money for covering other needs (Pham Van Hung and Nguyen Minh Hien, 2000)). In the near future, improvement of farmers' income and their purchasing power should be addressed to reducing relative prices between manufacture and agricultural products. However, Vietnam still has policies allowing for the dominance of the state--owned enterprises (SOEs), most of which are not profit making. The Government has planned to equitize or close one-third of the 5,300 SOEs in the coming three years, but the biggest SOEs are also operating inefficiently resulting in increased cost of production and living costs especially for farmers or people with low incomes. This means that a radical reform of SOEs sector and the banking sector is needed to improve farmers' incomes and incomes of the population as a whole.

\section{REFERENCES}

Andrew Steer, Nisha Agrawal, and Carrie Turk (World Bank), 2000. Vietnam 2010: Entering the 21 Century. Vietnam Development Report 2001. An Joint Report of World Bank, Asian Development Bank and UNDP for Consultative Group Meeting for Vietnam, December 14-15, 2000.

FAO, April 1999. Rural Development Chapter. A part of Common Country Assessment (CCA) for Vietnam. The draft by FAO Vietnam. Hanoi.

General Statistical Office (GSO). Vietnam Statistical Yearbooks (various years). Statistical Publishing House, Hanoi.

GSO, 1999. Statistical Data of Agriculture, Forestry and Fishery $1990-1998$ and Forecast in the Year 2000. Statistical Publishing House. Hanoi.

GSO, 2000. Vietnam Living Standard Survey 1997-1998. Statistical Publishing House. Hanoi.

Izumida, Yoichi, 2000. Agricultural Structure Problems in Vietnam. The University of Tokyo, Japan. Scientific Paper No. 00-F-002, July 2000.

Ministry of Agriculture and Rural Development (MARD), 2000. Some Legal Documents on Agricultural and Rural Development. The Labor and Social Publishing House. Hanoi, January 2000. (In Vietnamese).

Ministry of Labors, Invalid and Social Affair (MOLISA), Vietnam, 2000. New Criteria for Poverty in the Period of 2001-2005. Hanoi, November 2000. (In Vietnamese).

Nakachi, Soushun, 1999. Structure of Land Holding in Rural Areas and the 1993 Land Law. Paper submitted to the International Symposium "Changes in Vietnamese Agriculture under the Open Market Economy". November 1999.

Nguyen Sinh Cuc, 1995. Agriculture of Vietnam 1945-1995. Statistical Publishing House. Hanoi.

Pham Van Dinh, Takeshi Murata, and Pham Van Hung, 2000. Key Issues in the Process of Rural Economy Development in Vietnam. Faculty of Agriculture, Kyushu University.

Pham Van Hung and Nguyen Minh Hien, 2000. The Vegetable Marketing System. The paper presented in the Joint Workshop on Rural Economy Development in the Red River Delta of Vietnam between the Faculty of Economics and Rural Development, Hanoi Agricultural University (HAU) and HAU-JICA ERCB Project held at HAU, 26-28 June 2000.

Pham Van Hung, 1999. Inventory and Assessment of Innovative Financial Organizations Directed Towards the Poorer Population in Vietnam. A part of Multi-Country Project on Rural Financial Policies and Food Security for the Poor. Institute of Agricultural Economics and Social Sciences in the 
Tropics, University of Hohenheim and IFPRI. September, 1999.

UNDP Vietnam, 1999 and 2000. Socio-economic Statistical Bulletin. Hanoi.

UNDP Vietnam. Annual Report 1999, Hanoi.

Vali Jamal and Karel Jansen, 1998. Agrarian Transition in Vietnam. Working Paper, Sectoral Activities Program. International Labor Organization, Geneva.

World Bank Vietnam, 2000. Macroeconomic Update. Report paper. Hanoi, March, 2000.

World Bank Vietnam, 2000. Vietnam-Export Performance in 1999 and Beyond. An informal report prepared for the Mid-year Consultative Group Meeting, June 22-23, 2000. Hanoi. 